\title{
世界に役立つLCAを LCA Has Come to the Moment of Truth
}

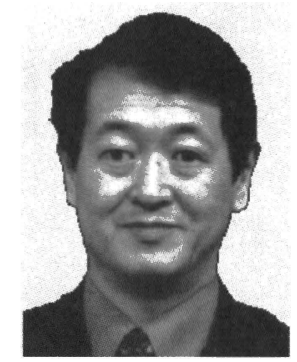

日本LCA 学会副会長 原田 幸明 Vice-chairman of The Institute of Life Cycle Assessment, Japan Kohmei HALADA

\section{「努力」から「解決」へ}

今年は洞爺湖サミットの年である。昨年のIPCCの第 4 次報告も受けて、世界は温暖化防止に全力で動き出そうと している。わが国のCool Earth 50構想をはじめ、世界各 国が中期的スパンで大胆な数值目標を掲げて、競い合うか のように政治・経済的課題としても取り組もうとしている。 いまや、地球環境問題に対する対応は「配慮」「努力」の 時代を終え、「解決」の段階に入ろうとしている。このよ うな時点に立って、LCAに何ができるのか、LCAはこの ままでよいのかを問い直してみる段階にきている。

\section{小さな「努力」の集まりは抜本的「解決」に結びつくか}

環境負荷低減に関するあらゆるところからの努力は重要 である。しかし、「個々の努力『しかない』から努力する」 のでは到底解決に至らない。 $50 \% 、 70 \%$ の $\mathrm{CO}_{2}$ 削減やファ クター 10 はおろかファクター 4 が達成されるには、大き なパラダイムシフトが求められており、その方向性は何な のか、それに向かっていかに歩き出すのかが問われている のが今なのである。それを個々の努力に還元するような風 潮は、世の中の環境負荷削隇の流れから村八分にされない 免罪符のゴミの山を作りかねず、地球環境のサステイナビ リティを個人や会社のサステイナビリティに矮小化してし まう危険性さえもっている。

かっては地球環境問題に気を配る人は少なく、またそれ を自らの行動や製品責任として取り組もうという主体は 少なかった。そのような時代にはLCAは、それらの努力 をその効果とあわせて分かりやすく示すッールとして有 効であった。しかし、世の中全体がその方向を向いたと き、LCAは何の役に立つのか考えてみるべきである。も しLCAが個々の努力に $0 \times$ を与えることに窮々とするな らば、免罪符としてのLCA需要は増えるだろうが、果た してそれでよいのだろうか。

\section{「精密な」LCAより「頑丈な」LCAを}

「正確な」LCA はなく、実施者の環境認識に基づく条件 設定がLCAの数值に影響を与える、ということはここで 繰り返すまでもないと思われる。そのような中で、これ までのLCAは個別の努力を際立たせるために「精密な」 LCAを追求してきた。しかしこれからが「努力」して「参加」 する主体を増やすことでなく、「解決」に向けた方向性を 探すことであるならば、LCAの力点は大きく変わらざる を得ない。まずLCAの比較評価が数\%オーダーの優劣で しか表されないようなシステム変更は求められているよう なパラダイムシフトにつながる性格のものではないだろう。 LCA は、このような努力の後付けから脱却して、現行の システムを徹底的に分析し、変革に結びつく大きな改善ポ イントの抽出を進める道具に進化していく必要がある。そ のためには、現存するプロセスのインベントリーデータに 依存しなくても大胆な議論のできる Robust (頑丈) なメソ ドロジー構築が不可欠である。また、プロセスの積み上げ ではなくシステム全体の枠組みからバウンダリを構成でき る俯瞰的論理構造が必要である。もちろんわが国のLCA 研究の中においてはこのような取り組みもいくつか見られ ている。しかしまだ世界のLCAに新しい風を吹かせると ころまでいっていない。世界がパラダイムシフトを志向し だした今、それに合致できる解析メソドロジーをどこから 発信しうるかは、パラダイムシフトの現実性に係わる競争 でもある。

\section{「単ー」インパクトからリスク「転嫁」の予見へ}

これまでの人類の歴史は、ある文明がリスクに面した場 合、その対面したリスクそのものよりも、関連事象に転嫁 されたリスクによりカタストロフィーに陥ったケースが多 い。特に、現在や戦時中の日本のように「猫も杓子も」の 傾向が強いほどその危うさが大きいことは言うまでもない。 このようなリスクの転嫁は、バイオマスのエネルギー利用、 
高効率エネルギーシステムのための希少資源の需要増など ですでにその一端は見えてきている。LCAは本来これら のインパクトを評価することが目指されていたが、その普 及期において「分かりやすく」することへの要請から単一 指標化が重視されてきた経緯がある。しかし、先述したよ うに「努力」の「普及」の段階から「解決」の段階に変わっ てきている現在においては、単一問題の解決に伴うリスク 転嫁をこそ予測できて意味がある。少なくとも天（気候変 動）、地（資源）、人（有害物質）の3つのリスクにかかわ るインパクトを転嫁の観点から評価できるシステムにして いく必要があるだろう。

環境インパクト間の重み付け、統合化から 個々のリスクの科学的な把握を

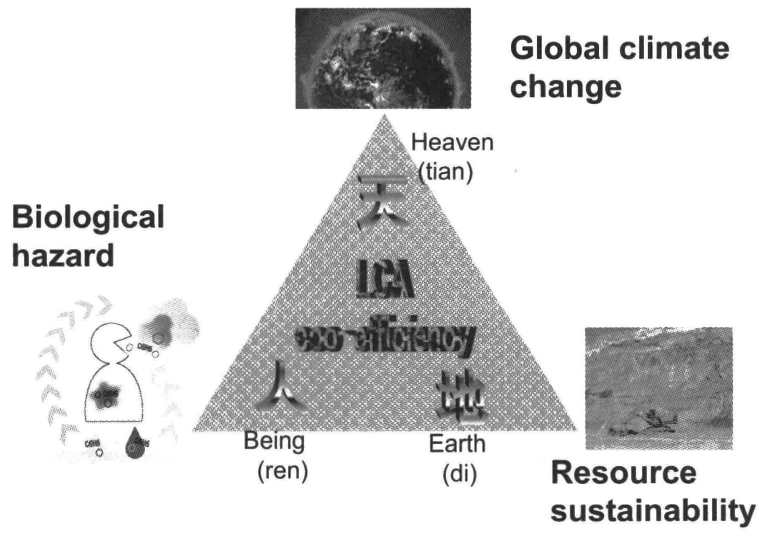

機能単位を「合わせる」から機能の「選択」へ

解釈、インパクトに関する部分を述べてきたからには、 インベントリーの課題にも触れておかねばなるまい。イン ベントリーの残された大きな課題のひとつは「異なる」機 能単位の問題であった。しかし、この問題も世界中がライ フスタイルの転換を意図しだすと小さな部分解の精緻さの 問題に縮小する。ライフスタイルの転換とは、異なる機能 単位への乗り換えであり、同一機能の維持から行動主体の もとめる機能の選択が問題となってくるからである。異な る機能を環境負荷の相当量で表し、行動主体の選択のため の情報とするような新たな方法論が機能単位の取り扱いに 対して発展させられていくべきであろう。

\section{「ムラ」の学会から「機能する」学会へ}

「学会をつくるとムラ意識で閉鎖的になる」ということ はよく指摘されることである。他の学会等との区別化、融 合的取り組みに対する堅実性、論文などで精緻さを競い敷 居を高くするなどは、ムラを守るためには必要な行為であ る。しかし先のような世界の状況を考えるならば、LCA 学会がムラ意識に浸っている层はない。LCAは今、新た な発展が求められている。かって寺山修二の「書を捨て街 に出よう」という言葉があるが、今LCA学会にもとめら れているのは「書を持ち、街に出よう」である。LCA学 会がそのような機能的な学会になることを期待する。世界 は動いている。LCAも変わらなければ!! 